\title{
Inner pelvic measurements in dairy breeds
}

\author{
Zoltán Szendrei ${ }^{1}$ - Mária Holcvart ${ }^{2}$ - Sándor Elek $^{2}$ - Katalin Hódi ${ }^{3}$ - Béla Béri ${ }^{2}$ \\ ${ }^{1}$ Munkácsy-Tej Kft., Gyula ${ }^{2}$ Debreceni Egyetem, Állattenyésztéstudományi és Biodiverzitás-védelmi Intézet, Debrecen ${ }^{3}$ Tesco Global \\ Áruházak Zrt., Budaörs \\ zoli.szendrei@gmail.com
}

Keywords: pelvic area, pelvimetry, Ayrshire, Brown Swiss, Holstein, Jersey, Norwegian Red, Swedish Red

\section{SUMMARY}

Dystocia causes great financial losses: due to dystocia milk production is decreased and the probability of calf loss is increased. There are many factors that may cause dystocia. One of the factors-often investigated in beef cattle-is pelvic measurements. There have not been inner pelvic measurement comparisons done on dairy breeds in Hungary.

After comparing the imported, primiparous cows, Jerseys turned out to have the smallest absolute inner pelvic measures. According to their age and weight, Brown Swiss cows had the largest pelvic dimensions. Ayrshire, Norwegian and Swedish Red, the three dairy breeds which share similar genetic background did not differ in most measures. Holsteins were closest to the apparent ideal 1:1 horizontal and vertical diameter ratio; however, this breed suffers the most from dystocia. Jerseys, despite having the smallest pelvic area are famous of their calving ease, perhaps not by coincidence. Although this dairy breed is the lightest, when the pelvic area was compared in ratio of body weight Jerseys were not smaller than the 130 and $114 \mathrm{~kg}$ heavier Norwegian and Swedish Red cows.

\section{INTRODUCTION}

Diseases and health problems negatively affect the productivity of dairy farming: reproductive potential is reduced, productive life is shortened and the quantity of milk produced is decreased. Directly or indirectly, dystocia results in great economic losses. In dairy cows, dystocia entails decreased milk production (Thompson et al, 1983; Dohoo et al, 1984; Djemali et al, 1987; Simerl et al, 1992; Dematawewa and Berger, 1997; Rajala and Grohe, 1998). Following dystocia, the prevalence of placenta retentions and metritis increases. These conditions lead to later conception and thus to the increase in the number of days between subsequent calvings (Erb et al, 1981, 1985, Curtis et al, 1985). Furthermore, dystocia also increases the chances of stillbirth and perinatal mortality rates (Laster et al, 1973, Smith et al, 1976, Patterson et al, 1979).

In practical terms, dystocia occur for three reasons: 1) a large calf does not fit through the dam's pelvis; 2) the fetus is not oriented properly; 3 ) weak labor. All three reasons can be traced back to genetic causes (Hansen et al, 2004) and to feeding and husbandry factors.

Numerous studies have addressed the examination of reasons underlying dystocia. The authors have revealed a close relationship between the sex and weight of the newborn calf, time of calving (season) and the dams' age (Rice and Wiltbank, 1970; Brinks et al, 1973; Pollak and Freeman, 1976; Rutter et al, 1983). Age have an impact on the development and live weight measured at different ages, and these on dystocia (Tyler et al, 1947, Blackmore et al, 1958; Touchberry and Legault, 1962; Sagebiel et al, 1969; Bellows et al. 1971; Singleton et al, 1973; Cadle and Ruttle, 1973). The shape of the pelvis in cattle - tall and narrower at the bottom than on the top (Bartosiewicz and Gere, 1979; White, 1980) disposes the race to dystocia, although in this respect, there is difference among the breeds and types (Cole et al, 2005).

Shape and size of the pelvis - regarding dystocia - have been studied worldwide (Rice and Wiltbank, 1972; Belcher and Frahm, 1979; Price and Wiltbank, 1978; Kriese et al, 1994) and nationwide in beef breeds (Holló and Horváth, 1979; Wagenhoffer et al, 2005; Nagy et al, 2007). However, the examination of dairy breeds are almost exclusively confined to the Holstein-Friesian breed (Sieber et al, 1988, 1989, Hoffman et al, 1996, Radcliff et al, 1997; Johanson and Berger, 2003; Lombard et al, 2007), and in our country, such studies have not been conducted.

Our goal was to find out whether there is any difference among dairy breeds regarding inner pelvic measurements.

\section{MATERIAL AND METHOD}

Vertical (height of pelvic, conjugata vera) and horizontal pelvic diameter (width of pelvic, diameter transversa intermedia) were measured with a Vissac pelvimeter. All measurements were taken by the same person in 2008-2009, at the dairy farm of the Körös-Maros Biofarm Kft. in Gyula. The cows examined were imported as pregnant heifers. Breed, origin of breed and number of cows are described in Table 1. 
Breed, origin, number of heads and age in months of the compared animals

\begin{tabular}{|l|l|c|c|}
\hline \multicolumn{1}{|c|}{ breed } & country of origin & number of cows & age (month) \\
\hline Ayrshire & Finland & 15 & $29,5 \mathrm{bc}$ \\
\hline Brown Swiss & Switzerland & 13 & $34,8 \mathrm{a}$ \\
\hline Holstein-Friesian & Hungary & 13 & $31,9 \mathrm{~b}$ \\
\hline Jersey & United Kingdom & 14 & $28,1 \mathrm{c}$ \\
\hline Norwegian Red & Norway & 15 & $30,3 \mathrm{bc}$ \\
\hline Swedish Red & Sweden & 11 & $30,2 \mathrm{bc}$ \\
\hline total/average & & 81 & $30,7 \mathrm{bc}$ \\
\hline
\end{tabular}

Different letters $(a, b)$ in the same column mark significant difference at $\mathrm{p}<0.05$ level.

Dividing the height of the pelvis by its width, the diameter ratio describing the shape of the pelvis (wide $<1$ (round) <high) was obtained. Pelvic area was calculated using the following formula: $\mathrm{T}=\mathrm{a} \times \mathrm{b} \times \pi$, where $\mathrm{a}=$ half the vertical diameter, $\mathrm{b}=$ half the horizontal diameter, $\pi=$ Pythagoras' constant. Ratio of pelvic area in relation to body weight was calculated and is expressed in $\mathrm{kg} / \mathrm{cm}^{2}$.

Data were analyzed using the SPSS 17.0 program (SPSS, 2008): homogeneity of variance was tested using Levene's test and an independent sample t test was used to compare means.

\section{RESULTS}

\section{Vertical pelvic diameter}

Vertical diameter of the pelvis in Jerseys proved to be the smallest when the six breeds were compared (Table 2). Pelvic height of Brown Swiss cows (the breed with the oldest cows: 34.8 months) differed significantly only from the smallest sized Jerseys $(351 \mathrm{~kg})$ and the second largest Holstein $(509 \mathrm{~kg})$ cows, but was similar to the younger and smaller-bodied Scandinavian breeds.

Vertical pelvic diameter measures (cm)

\begin{tabular}{|l|c|c|c|c|c|c|}
\hline & $\mathbf{n}$ & average & deviation & $\begin{array}{c}\text { relative } \\
\text { deviation }\end{array}$ & minimum & maximum \\
\hline AY & 15 & $21,5 \mathrm{bc}$ & 1,4 & 6,4 & 19,0 & 23,5 \\
\hline BS & 13 & $22,5 \mathrm{c}$ & 1,5 & 6,5 & 20,0 & 25,0 \\
\hline HF & 13 & $20,9 \mathrm{~b}$ & 1,4 & 6,7 & 18,0 & 22,5 \\
\hline JE & 14 & $19,4 \mathrm{a}$ & 2,0 & 10,2 & 14,0 & 22,0 \\
\hline NR & 15 & $21,9 \mathrm{bc}$ & 1,0 & 4,7 & 20,0 & 23,5 \\
\hline SR & 11 & $22,4 \mathrm{c}$ & 1,3 & 6,2 & 21,0 & 25,0 \\
\hline \multicolumn{2}{|c|}{ average } & 21,4 & 1,8 & 8,2 & 14,0 & 25,0 \\
\hline
\end{tabular}

Different letters $(a, b)$ in the same column mark significant difference at $\mathrm{p}<0.05$ level.

Table 2

\section{Horizontal pelvic diameter}

Regarding horizontal pelvic diameter, Holstein do not differ from Brown Swiss but exceed the measurements for Ayrshire, Norwegian and Swedish Red cows (Table 3). Among breeds, Jersey has the narrowest pelvic width. CV\% is greater in horizontal measures (9.37) than in vertical measures (8.22) and thus demonstrates the lessons learned during measurement taking: measurement points of the horizontal diameter are more difficult to palpate, measurement error is more likely. Both the largest and the second smallest diameter were found in the Brown Swiss breed.

Horizontal pelvic diameter measures (cm)

\begin{tabular}{|l|c|c|c|c|c|c|}
\hline & $\mathbf{n}$ & average & deviation & $\begin{array}{c}\text { relative } \\
\text { deviation }\end{array}$ & & minimum \\
\hline AY & 15 & $18,5 \mathrm{c}$ & 1,1 & 5,7 & 17,0 & 21,0 \\
\hline BS & 13 & $19,3 \mathrm{bc}$ & 2,3 & 12,1 & 16,0 & 25,0 \\
\hline HF & 13 & $20,2 \mathrm{~b}$ & 1,2 & 6,0 & 17,0 & 22,0 \\
\hline JE & 14 & $17,2 \mathrm{a}$ & 1,7 & 9,8 & 15,0 & 21,0 \\
\hline NR & 15 & $18,6 \mathrm{c}$ & 1,1 & 5,7 & 16,5 & 20,0 \\
\hline SR & 11 & $18,5 \mathrm{c}$ & 1,6 & 8,8 & 15,0 & 20,0 \\
\hline \multicolumn{2}{|l|}{ average } & 18,7 & 1,8 & 9,4 & 15,0 & 25,0 \\
\hline
\end{tabular}

Different letters $(a, b)$ in the same column mark significant difference at $\mathrm{p}<0.05$ level. 


\section{Ratio of vertical and horizontal diameter}

Table 4 contains the ratios calculated from the two previously reported figures. For pigs and ruminants, pelvic openings are vertically oval although there is a considerable difference among the breeds. The breeds included in the comparison are similar to one another; their pelvis is oval and is different from that of the Holstein. The pelvis is almost round in Holsteins, which might be considered preferable. Despite the theoretically ideal shaped pelvis, calving difficulties are most common in this breed. Low and wide pelvis was only found in some of the Brown Swiss, Holstein and Jersey cows. An extremely high and narrow pelvic opening was found in Ayrshire, Brown Swiss and Swedish Red breeds. Since in Brown Swiss both very low and very high pelvis forms occur, the value of the relative standard deviation is the highest here.

Table 4

Ratios of vertical and horizontal pelvic diameters

\begin{tabular}{|l|c|c|c|c|c|c|}
\hline & $\mathbf{N}$ & average & deviation & $\begin{array}{c}\text { relative } \\
\text { deviation }\end{array}$ & minimum & maximum \\
\hline AY & 15 & $1,17 \mathrm{~b}$ & 0,11 & 9,40 & 1,03 & 1,38 \\
\hline BS & 13 & $1,18 \mathrm{~b}$ & 0,14 & 13,46 & 0,80 & 1,39 \\
\hline HF & 13 & $1,04 \mathrm{a}$ & 0,11 & 10,57 & 0,82 & 1,24 \\
\hline JE & 14 & $1,17 \mathrm{~b}$ & 0,13 & 11,11 & 0,90 & 1,31 \\
\hline NR & 15 & $1,18 \mathrm{~b}$ & 0,08 & 6,77 & 1,05 & 1,33 \\
\hline SR & 11 & $1,22 \mathrm{~b}$ & 0,12 & 9,83 & 1,08 & 1,47 \\
\hline average & 1,16 & 0,13 & 11,20 & 0,80 & 1,47 \\
\hline
\end{tabular}

Different letters $(a, b)$ in the same column mark significant difference at $\mathrm{p}<0.05$ level.

\section{Pelvic area}

Based on the pelvic area - calculated from the diameters- there is least room in Jerseys for a calf to be born. However, this breed is well-known for the ease of calving (Table 5). Numerically, the Brown Swiss has the largest pelvic diameter, although statistically, the pelvis is not different to the others, except in the case of the Ayrshire. The Jersey data has the greatest; the Holstein has the least standard deviation.

Pelvic area in $\mathbf{c m}^{2}$

\begin{tabular}{|l|c|c|c|c|c|c|}
\hline & n & average & deviation & $\begin{array}{c}\text { relative } \\
\text { deviation }\end{array}$ & minimum & maximum \\
\hline AY & 15 & $311 \mathrm{c}$ & 24 & 8 & 269 & 363 \\
\hline BS & 13 & $341 \mathrm{bc}$ & 44 & 13 & 251 & 393 \\
\hline HF & 13 & $330 \mathrm{bc}$ & 22 & 7 & 280 & 363 \\
\hline JE & 14 & $263 \mathrm{a}$ & 38 & 14 & 165 & 330 \\
\hline NR & 15 & $320 \mathrm{bc}$ & 26 & 8 & 280 & 361 \\
\hline SR & 11 & $325 \mathrm{bc}$ & 38 & 12 & 259 & 373 \\
\hline \multicolumn{2}{|l|}{ average } & 314 & 41 & 13 & 165 & 393 \\
\hline
\end{tabular}

Different letters $(a, b)$ in the same column mark significant difference at $\mathrm{p}<0.05$ level.

\section{Pelvic diameter in relation to body weight}

In the previous tables $(2,3,5,6)$, breeds were compared through absolute dimensions. To ensure that the differences distorting the comparisons disappear, the ratio of pelvic area and body weight was calculated and evaluated (Table 6). The comparison provided the following results: although the Jersey cows can be characterized to be the smallest in all respects, by absolute dimensions, when pelvic diameter is compared to body weight, then their size equal to that of Norwegian and Swedish Red cows.

Pelvic area relative to body weight

\begin{tabular}{|l|c|c|c|c|c|c|}
\hline & $\mathbf{n}$ & average & deviation & $\begin{array}{c}\text { relative } \\
\text { deviation }\end{array}$ & minimum & maximum \\
\hline AY & 15 & $1,53 \mathrm{~b}$ & 0,20 & 13,07 & 1,15 & 1,86 \\
\hline BS & 13 & $1,55 \mathrm{~b}$ & 0,31 & 20 & 1,21 & 2,43 \\
\hline HF & 13 & $1,54 \mathrm{~b}$ & 0,11 & 7,14 & 1,38 & 1,74 \\
\hline JE & 14 & $1,36 \mathrm{a}$ & 0,20 & 14,7 & 1,01 & 1,78 \\
\hline NR & 15 & $1,51 \mathrm{ab}$ & 0,12 & 7,94 & 1,28 & 1,67 \\
\hline SR & 11 & $1,46 \mathrm{ab}$ & 0,21 & 14,3 & 1,23 & 1,79 \\
\hline \multicolumn{2}{|l}{ average } & 1,49 & 0,20 & 13,4 & 1,01 & 2,43 \\
\hline
\end{tabular}

Different letters $(a, b)$ in the same column mark significant difference at $\mathrm{p}<0.05$ level. 


\section{CONCLUSIONS}

Bellows et al (1971) and Cadle and Ruttle (1973) also found that heifers were smaller-bodied (lighter) at the age of one year and experience more calving difficulty. Although Singleton et al (1973) found that dystocia almost exclusively depends on the weight of the dam and lighter heifers calved more easily. However, Rutter et al. (1983) associated the weight of the calf with dystocia as did previously Bellows et al, (1971), as well as Rice and Wiltbank (1972). Instead of the simply measurable weight, Price and Wiltbank (1978) associated dystocia with the pelvic area. In 1980, Thompson et al, found that there is an important relationship between a cow's body size and dystocia: cows reaching high overall body scores -being taller- had dystocia more likely than smaller framed ones. In contrast, Ali et al (1984) have concluded that those cows which were larger framed with a large, slightly sloping pelvis, calved more easily than others. Similarly, Sieber et al (1989) found that small cows with a short pelvis calved with more difficulties than big framed ones with a well developed pelvis.

Our comparison revealed that Jerseys have the smallest internal pelvic dimensions. This is not surprising, since all other external dimensions of this breed are the least among the compared breeds. Despite this finding, this breed is famous for its calving ease. According to their age and body weight, Brown Swiss cows have the greatest dimensions. Ayrshire, Swedish Red and Norwegian Red breeds -with common genetic backgroundmostly did not differ from each other. The Holstein pelvis is closest to the apparently ideal horizontal and vertical diameter ratio of 1:1; however, this breed suffers most from dystocia.

The Jersey breed, which has the smallest pelvic area, is famous for its calving ease - perhaps not coincidentally, because even though it is the lightest of dairy breeds, when pelvic diameter is expressed in the ratio of body weight, this figure is not less than that of Norwegian and Swedish Red cows, which are 130 and $114 \mathrm{~kg}$ heavier, respectively.

We believe that including calf birth weight and body measurements in the comparisons can better explain the relationship between dystocia and body measurements.

The study was financed by NKFP_A7_03 TEJUT_08 (OM-00060/2008).

\section{REFERENCE}

Ali, T. E.-Burnside, E. B. és Schaeffer, L. R. (1984): Relationships between external body measurements and calving difficulties in Canadian Holstein-Friesian cattle. J. Dairy Sci. 67:3034.

Belcher, D. R.-Frahm, R. R. (1979): Factors affecting calving difficulty and the influence of pelvic measurements on calving difficulty percentage in Limousin heifers. Anim. Sci. Research Report, Oklahoma State Univ., April. 136-144.

Bellows, R. A.-Short, R. E.-Anderson, D. C.-Knapp B. W.-Pahnish, O. F. (1971): Cause and effect relationships associated with calving difficulty and birth weight. J. Anim. Sci. 33:407-415.

Blackmore, D. W.-McGilliard, L. D.-Lush, J. L. (1958): Genetic relations between body measurements at three ages in Holsteins. J. Dairy Sci. 41:1045-1049.

Brinks, J. S.-Olson, J. E.-Carroll, E. J. (1973): Calving difficulty and its association with subsequent productivity in Herefords. J. Anim. Sci. 36:11-17.

Cadle, J. M. Jr.-Ruttle, J. L. (1973): Dystocia in range beef heifers. J. Anim. Sci. 43:227 (Abstr.).

Cole, J. B.-Goodling, R. C.-Wiggans, G. R. (2005): Genetic evaluation of calving ease for Brown Swiss and Jersey bulls from purebred and crossbred calvings, J. Dairy Science, 88. 4. 1529-1539.

Curtis, C. R.-Erb, H. N.-Sniffen, C.J.-Smith, R D.-Kronfeld, D. S. (1985): Path analysis of dry period nutrition, postpartum and reproductive disorders, and mastitis in Holstein cows. J. Dairy Sci. 68:2347-2360.

Dematawewa, C. M. B.-Berger, P. J. (1997): Effect of dystocia on yield, fertility, and cow losses and an economic evaluation of dystocia scores for Holsteins. J. Dairy Sci. 80:754-761.

Djemali, M.-Freeman, A. E.-Berger, P. J. (1987): Reporting of dystocia scores and effects of dystocia on production, days open, and days dry from Dairy Herd Improvement data. J. Dairy Sci. 70:2127-2131.

Dohoo, I. R.-Martin, S. W. (1984): Disease, production and culling in Holstein-Friesians cows. IV. Effects of disease on production. Prev. Vet. Med. 2:755-770.

Erb, H.N.-Martin, S. W.-Ison, N.-Swaminathan, S. (1981): Interrelationships between production and reproductive diseases in Holstein cows. Conditional relationships between production and disease. J. Dairy Sci. 64:272-281.

Erb, H. N.-Smith, R D.-Oltenacu, P. A.-Guard, C. L.-Hillman, R. B.-Powers, P. A.-Smith, M. C.-White, M. E. (1985): Path model of reproductive disorders and performance, milk fever, mastitis, milk yield and culling in Holstein cows. J. Dairy Sci. 68:3337-3349.

Fehér Gy. (1980): A háziállatok funkcionális anatómiája. Mezőgazdasági Kiadó.

Gere T.-Bartosiewicz L. (1979): Az elléssel kapcsolatos testméretek alakulása húsmarhák esetében. Állattenyésztés. 28.4. 343-348.

Hansen, M.-Misztal, I.-Lund, M. S.-Pedersen, J.és Christensen, L. G. (2004): Undesired Phenotypic and Genetic Trend for Stillbirth in Danish Holsteins. J. Dairy Sci. 87:1477-1486.

Hoffman, P. C.-Brehm, N. M.-Price, S. G.-Prill-Adams, A. (1996): Effect of Accelerated Postpubertal Growth and Early Calving on Lactation Performance of Primiparous Holstein Heifers. J. Dairy Sci. 79:2024-2031.

Holló I.-Horváth Á. (1979): Előzetes beszámoló a tehenek medenceméretei és az ellés lefolyása közötti összefüggés vizsgálatáról. Állattenyésztés. 28. 1. 21-26. 
Johanson, J. M.-Berger, P. J. (2003): Birth Weight as a Predictor of Calving Ease and Perinatal Mortality in Holstein Cattle. J. Dairy Sci. 86:3745-3755.

Kriese, L. A.-Van Velck, L. D.-Gregory, K. E.-Boldman, K. G.-Cundiff, L. V.-Koch, R. M. (1994): Estimates of Genetic Parameters for 320day Pelvic Measurements of Males and Females and Calving Ease of 2-year-old Females. J. Anim. Sci. 72. 1954-1963.

Laster, D. B.-Glimp, H. A.-Cundiff, L. V.-Gregory, K. E. (1973): Factors affecting dystocia and the effects of dystocia on subsequent production in beef cattle. J. Anim. Sci. 33:695-705.

LeGault, C. R.-Touchberry, R. W. (1962): Heritability of birth weight and its relationship with production in dairy cattle. J. Dairy Sci. 45:1226-1233.

Nagy B.-Király I.-Bene Sz.-Dákay I.-Szabó F. (2007): Magyar szürke tehenek és üszők külső és belső medence méreteinek vizsgálata. Állattenyésztés és takarmányozás, 56. 3. 205-211.

Patterson, D. J.-Bellows, R. A.-Burfening, P. J.-Short, R. E.-Carr, J. B. (1979): Incidence and causes of neonatal and postnatal mortality in range cattle. J. Anim. Sci. 49(Suppl. 1): 325.

Pollak, E.J.-Freeman, A.E. (1976): Parameter Estimation and Sire Evaluation for Dystocia and Calf Size in Holsteins. J. Dairy Sci. 59:18171824 .

Lombard, J. E.-Garry, F. B.-Tomlinson, S. M.-Garber, L. P. (2007): Impacts of Dystocia on Health and Survival of Dairy Calves. J. Dairy Sci. 90:1751-1760.

Price, T. D.-Wiltbank, J. N. (1978): Predicting dystocia in heifers. Theriogenology 9:221-249.

Rajala, P. J.-Gröhn, Y. T. (1998): Effects of Dystocia, Retained Placenta, and Metritis on Milk Yield in Dairy Cows. J. Dairy Sci. 81:31723181.

Radcliff, R. P.-VanDeHaar, M. J.-Skidmore, A. L.-Chapin, L. T.-Radke, B. R.-Lloyd, J. W.-Stanisiewski, E.P.-Tucker, H. A. (1997): Effects of Diet and Bovine Somatotropin on Heifer Growth and Mammary Development J. Dairy Sci. 80:1996-2003.

Rice, L. E.-Wiltbank, J. N. (1972): Factors affecting dystocia in beef heifers. J. Amer. Vet. Med. Assoc. 161:1348-1358.

Rice, L. E.-Wiltbank, J. N. (1970): Dystocia in beef heifers. J. Anim. Sci. 30:1043 (Abstr.)

Rutter, L. M.-Ray, D. E.-Roubicek, C. B. (1983): Factors Affecting and Prediction of Dystocia in Charolais Heifers. J. Anim. Sci. 57:10771083.

Sieber, M.-Freeman, A. E.-Kelley, D. H. (1988): Relationships Between Body Measurements, Body Weight, and Productivity in Holstein Dairy Cows. J. Dairy Sci. 71:3437-3445.

Sieber, M.-Freeman, A. E.-Kelley, D. H. (1989): Effects of Body Measurements and Weight on Calf Size and Calving Difficulty of Holsteins. J. Dairy Sci. 72:2402-2410.

Sagebiel, J. A.-Krause, G. F.-Sibbit, B.-Langford, L.-Comfort, J. E.-Dyer, A. J.-Lasley, J. F. (1969): Dystocia in reciprocally crossed angus, Hereford and Charolais cattle. J. Anim. Sci. 29:245.

Singleton, W. L.-Nelson, L. A.-Huber, D. A. (1973): Factors influencing dystocia in two year old heifers. J. Anim. Sci. 37:251 (Abstr.).

Simerl, N. A.-Wilcox, C. J.-Thatcher, W. W. (1992): Postpartum performance of dairy heifers freshening at young ages. J. Dairy Sci. 75:590595.

Smith, G. M.-Laster, D. B.-Gregory, K. E. (1976): Characterization of biological types of cattle. 1. Dystocia and preweaning growth. J. Anim. Sci. 43:27-36.

SPSS for Windows, Rel. 17.0.0. 2008. Chicago: SPSS Inc.

Thompson, J. R.- Freeman, A. E.-Berger, P. J. (1980): Relationship of dystocia transmitting ability with type and production transmitting ability in Holstein bulls. J. Dairy Sci. 63:1462

Thompson, J. R.-Pollak, E. J.-Pelissier, C. L. (1983): Interrelationships of parturition problems, production of subsequent lactation, reproduction, and age at first calving. J. Dairy Sci. 66:1119-1127.

Tyler, W. J.-Chapman, A. B.-Dickerson, G. E. (1947): Sources of variation in the birth weight of Holstein-Friesian calves. J. Dairy Sci. 30:483-498.

Wagenhoffer Zs.-Király I.-Szabó F. (2005): Húshasznú tehenek és üszők belsőmedence átmérőinek vizsgálata, különös tekintettel a fehérkék belga fajtára. Állattenyésztés és Takarmányozás. 54. 1. 1-14. 